§I，目的およひ思考の方針

I・1 目的 われわれはさき空気中の水分が有機

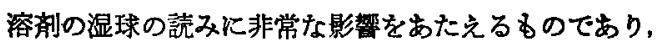
したがって有機容郕の湿度線図から溶剂の湿球温度 $t_{a 1}$ を推算する場合には，大きな修正を施す必要のあること

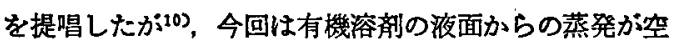
気中の水分によって，どの上ろに影響されるかを検討し た。

I·2 思考の方針 溶剤が乾燥空気中へ蒸発する場 合の伝熱平衡式は

$$
k^{\prime} r_{a}\left(H_{a 1}{ }^{\prime}-H_{a}\right)=h_{s}\left(t-t_{a 1}{ }^{\prime}\right)
$$

つき空気中に水蒸気がらくまれる，水分の凝縮な どによる熱量 $g_{w}$ が付加されることが考えられるので

$$
k^{\prime} r_{a}\left(H_{a 1}-H_{a}\right)=h_{a}\left(t-t_{a 1}\right)+q_{w}
$$

とかきうる。(2) 式から (1) 式を引くと,

$$
\begin{aligned}
& k^{\prime} r_{a}\left(H_{a 1}-H_{a}\right)-k^{\prime} r_{a}\left(H_{a 1}{ }^{\prime}-H_{a}\right) \\
= & q_{w}-h_{a}\left(t_{a 1}-t_{a 1}{ }^{\prime}\right)
\end{aligned}
$$

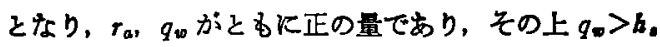
$\times\left(t_{a 1}-t_{a 1}{ }^{\prime}\right)$ であるなら，(3) 式より

$$
k^{\prime}\left(H_{a 1}-H_{a}\right)>k^{\prime}\left(H_{a 1}{ }^{\prime}-H_{a}\right)
$$

そいらことが考えられる。つまり，湿潤空気をつか 5 と $H_{a 1}>H_{a 1}{ }^{\prime}$ となって乾燥空気を使う場合より, よけい似 蒸発することが予想される。

上のようなことが確か炕こりうるすのであるかとう かを有機溶肪としてトルエン，四塩化炭素。 エチルフルコール, メチルフルコールを使 用し, 空気の温度, 湿度をかえた場合につ いて確かめ, かつ空気流速をかえた場合の 影響をも調へててみた。

\section{§II. 実駼聲谓}

蒸発室 $\mathrm{E}$ に完全乾燥空気と湿洞空気を括 くるために Fig.1 のごとき装㙕を組立て た。乾燥空気を送ろうとする場合にはバル ブ $\mathrm{B}_{3}, \mathrm{~B}_{5}$ を閉し， バルブ $\mathrm{B}_{2}, \mathrm{~B}_{1}$ 获開いて $\mathrm{D}_{1} \sim \mathrm{P}_{2}$ の吸着剤を入れた容器を通し，さ らに加熱器 $\mathrm{H}_{3}$ にて所要の温度におげて蒸 発室E汇導いた。乾燥空気の完全度は，乾

* 昭和 32 年 12 月 3 日受理

* 大阪市立大学理工学部

$$
\text { 吉田哲夫林.兵働務** }
$$

湿温度計 $\mathrm{R}$ 読みならびそバルブ $\mathrm{B}_{7}$ 付近で空気をぬき

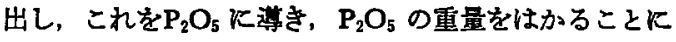
よって検定した。

湿潤空気をおくるためにはバルプ $\mathrm{B}_{2} ， \mathrm{~B}_{4}$ を閉し， ハ ルブ $\mathrm{B}_{3} ， \mathrm{~B}_{5}$ を開いてます空気を加熱器 $\mathrm{H}_{1}$ におくり, 年温し，それを增湿简下に導き必要水分をあたえた。 はラシヒリング充填塔で下方の温水タンクの水をポンブ MKよって循環する方式である。塔頂より出た空気を廿 イクロン $\mathrm{Y}_{1} ， \mathrm{Y}_{2}$ に通し，同伴された飛洙を除去し，そ れをさらに加熱器 $\mathrm{H}_{3}$ で所要の温度にあげて後蒸発室 $\mathrm{E}$ に導いた。そのさい乾湿温度計 Rの読みが所望のるの なるよう温度および湿度の調節は $S_{1} ， S_{2}, S_{3}$ ならびに ギヤーポンブMの回転数によって和こなった。所要風量 はハルブ $B_{1}$ で調節し，オリフィスOにてよみとった。

Fig. 2 Kしめされているのは繁発室 $\mathrm{E}$ の立面図，平 面図であり，Eの外枠は木製でその外側を厚さ䄪 $7 \mathrm{~cm}$ のガラスウールで保温した。蒸発さすべき溶倣を上部の ビューレットからガラス蒸発血に注入し，かつ蒸発 時に夜準計の読みが一定を保つようKたえずビューレッ トより液を注入し，その注入量をるって蒸発量とした。 湿润空気についての実験の場合には空気中の水蒸気が液 体の形て蒸発皿の中に浸入する。その量は最大の場合で 蒸発血の容積 $10.454 \mathrm{cc}$ K対して約 $0.036 \mathrm{cc} / \mathrm{min}$ であ りしたがって夜準計のよみは毎分約 $0.057 \mathrm{~mm}$ くるっ

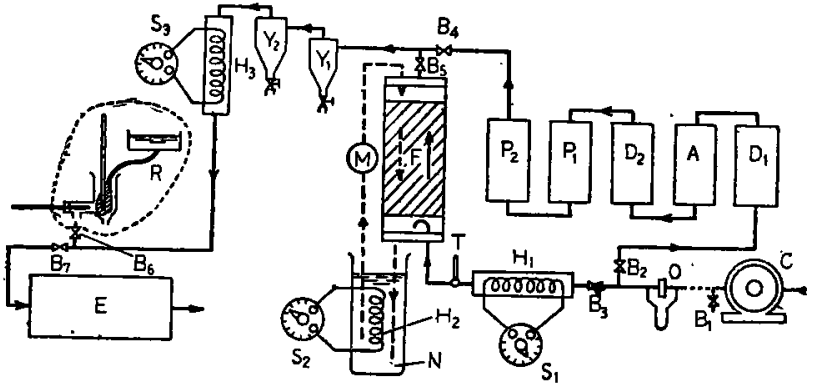

\footnotetext{
A : Active-Carbon-packed Column

$\mathrm{B}_{1}, \mathrm{~B}_{2}, \mathrm{~B}_{3}$ : Valve

C: Rotary blower

$\mathrm{D}_{1}, \mathrm{D}_{2}$ : $\mathrm{CaCl}$-packed column

E : Vaporization chamber

F : Humidifier
}

H1, $\mathrm{H}_{2}, \mathrm{H}_{3}$ : Electric beater
M: Gear pump

$N$ : Circulating-water tank

$O$ : Orifice

$\mathrm{P}_{1}, \mathrm{P}_{3}$ : $\mathrm{P}_{2} \mathrm{O}_{5}$-packed column

$R$ : Psychrometer

$\mathrm{S}_{1}, \mathrm{~S}_{2}, \mathrm{~S}_{8}$ : Slidac

$T$ : Thermometer

$Y_{1}, Y_{8}$ : Cyclone

Fig. 1 Sketch of apparatus 


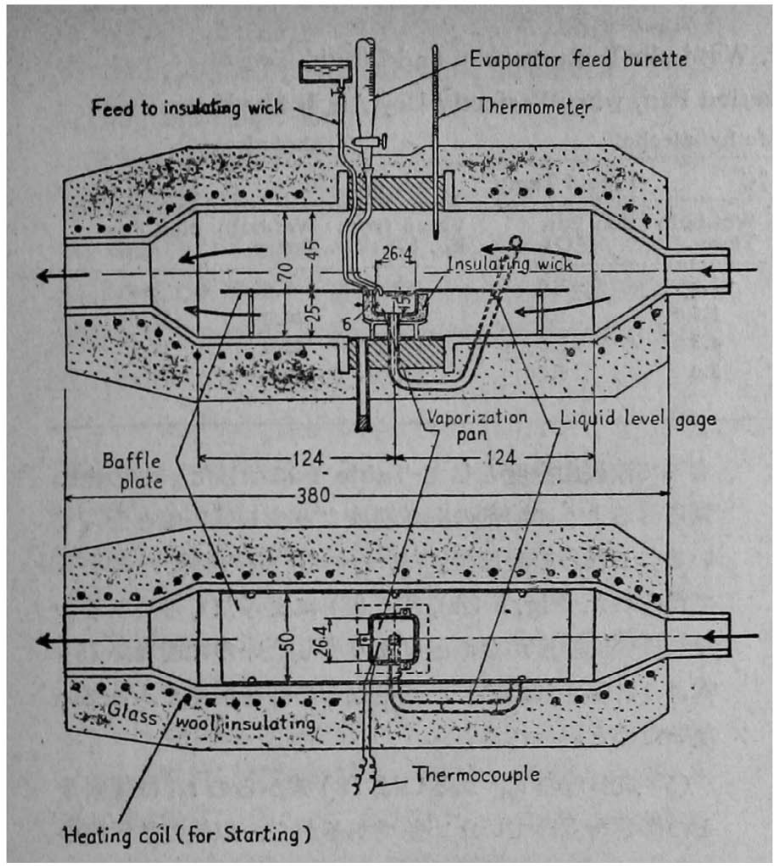

Fig. 2 Vaporization chamber

てくることになるので測定毎にこれを補正した。 蒸発血の外周には漏草 $6 \mathrm{~mm}$ の厚さに重ねて巻き， それに上方に配置したタンクより蒸発さすべき溶剤と同 ‘液を微量ずつ注ぎ，た方漏紙が湿潤の状態にあるよ 了Kし，その蒸発作用灴って外熱の浸入を防き，皿の 外周ができる限りその液の湿球温度附近にあるようにし た。そしてまた漏紙よりの蒸発蒸気が蒸発血の蒸発に影

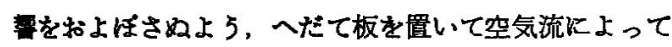
速か外部に放出されるようにした。皿の液温は熱電対 (0,1 $\mathrm{mm} \phi$ の銅ーシンスタンタン), とポテンショメータ で計り, 空気温度は皿の前後汇抽かれた 2 本の細径の水 銀温度計て測定し，それらの読みの算術平均をとって空 気温度とした。な和スタートKあたって蕁発室の周团に まかれた電熱線によって蒸発室が通過さすへき空気の温 度火ほほ等しくなるように加熱し，“空気を通し始めて 後、電流をきるようにした。

\section{§III. 実験結果と計算式}

测定結果の平均値をあらわす線图が， Fig. 3 括よび Fig. 4 である。これらの图炕䇣雑をさけるためにメ チルアルコールの記入を除外し, かつ四塩化炭菜性水上 り比重が大なるため㠜綰した水が液面炕浮〈関保上，よ いデータを得ることができなかったので、これについて の考察を恃ふいた。雨因にみることく、いずれの場合に 出いてる比較湿度の大きい空気を使った方があきらが

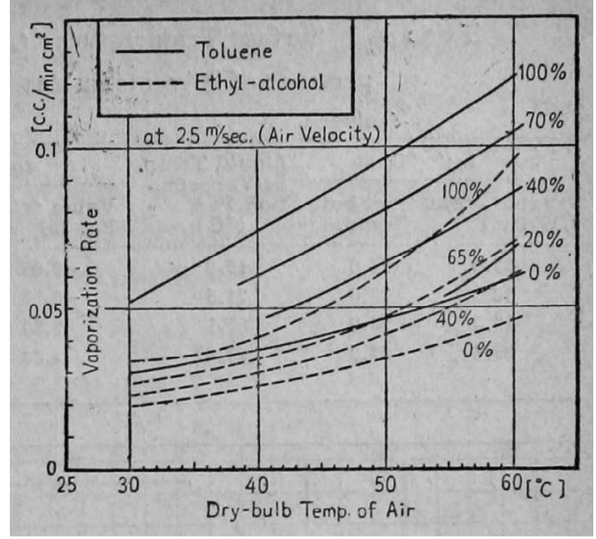

Fig. 3 Average curves for vaporization rate vs. air temperature ( $\%=$ Humidity percentage of water vapor in air)

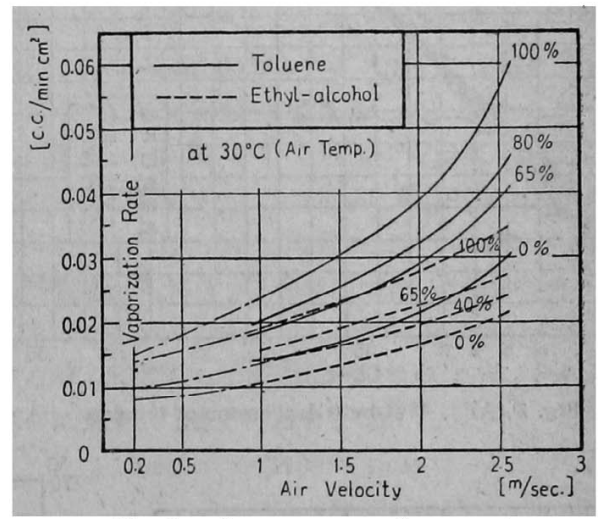

Fig. 4 Average curves for vaporization rate vs. air velocity ( $\%=$ Humidity percentage of water vapor in air)

蒸発量が多いことを知る。このことはわれわれの予想の 正しかったことを上記の三つの溶剤について実験的に荛 つけたことになる。

\section{III·1 空気の温度と湿度による影響}

(i) 乾焻空気の場合 Sc, $\operatorname{Pr}=0.5 \sim 2.5$ の範囲 Kおいて

$$
h / k^{\prime}=\left(S_{c} / P_{r}\right)^{1 / 2} \cdot c
$$

が成立することがわかっている5゙。われわれの今回の実 験るこの簐囲に入る。それで（4）式を（1）式に代入す ると,

$$
r_{a}\left(H_{a 1}{ }^{\prime}-H_{a}\right)=\left(S_{c} / P r\right)^{1 / 2} \cdot c \cdot\left(t-t_{a 1}{ }^{\prime}\right)
$$

(5) 式において $r_{a},\left(S_{C} / P_{T}\right)^{1 / 2} \cdot c$ は既知であり，また， 溶成蒸気を含んでいない空気を送っているから $H_{\mathrm{a}}=0$ そ拁ける。よって空気温度 $t$ を指定して，その時の夜面 温度 $t_{a 1}{ }^{\prime}$ を計算することができる。液表面温度を実测す ることはむずかしいので（5）式より計算された温度を 
Table 1 Surface Temperature $\left(t_{a 1}{ }^{\prime}\right)$, Wet-bulb Temperature, and Liquid Temperature of Solvents in Vaporization Pan, when Perfectly Dry Air Is Used

\begin{tabular}{|c|c|c|c|c|c|c|c|c|c|}
\hline \multirow{3}{*}{$\begin{array}{c}\text { Air } \\
\text { Temp. } \\
t^{\circ} \mathrm{C}\end{array}$} & \multicolumn{3}{|c|}{ Toluene } & \multicolumn{3}{|c|}{ Methyl-alcohol } & \multicolumn{3}{|c|}{ Ethyl-alcohol } \\
\hline & \multicolumn{2}{|c|}{$\tan ^{\prime}{ }^{\circ} \mathrm{C}$} & \multirow{2}{*}{$\begin{array}{l}\text { Liquid Temp. } \\
\text { in Vaporiza- } \\
\text { tion Pan } \\
\left({ }^{\circ} \mathrm{C}\right)\end{array}$} & \multicolumn{2}{|c|}{$\tan ^{\prime}{ }^{\circ} \mathrm{C}$} & \multirow{2}{*}{$\begin{array}{l}\text { Liquid Temp. } \\
\text { in Vaporiza- } \\
\text { tion Pan } \\
\left({ }^{\circ} \mathrm{C}\right)\end{array}$} & \multicolumn{2}{|c|}{$\operatorname{ta1}^{\prime}{ }^{\circ} \mathrm{C}$} & \multirow{2}{*}{$\begin{array}{l}\text { Liquid Temp. } \\
\text { in Vaporiza. } \\
\text { tion Pan } \\
\left({ }^{\circ} \mathbf{C}\right)\end{array}$} \\
\hline & $\begin{array}{l}\text { Value from } \\
\text { Eq. (5) }\end{array}$ & $\begin{array}{l}\text { Wet.bulb } \\
\text { Temp. }\end{array}$ & & $\begin{array}{l}\text { Value from } \\
\text { Eq. (5) }\end{array}$ & $\begin{array}{l}\text { Wet.bulb } \\
\text { Temp. }\end{array}$ & & $\begin{array}{l}\text { Value from } \\
\text { Eq. (5) }\end{array}$ & $\begin{array}{l}\text { Wet.bulb } \\
\text { Temp. }\end{array}$ & \\
\hline 30 . & 13.0 & 14.0 & 15.0 & -2.85 & -1.6 & -1.0 & 5.00 & 7.0 & 7.4 \\
\hline $40^{\circ}$ & 18.0 & 19.0 & 21.5 & -0.07 & 1.5 & 1.8 & 8.15 & 10.3 & 11.1 \\
\hline 50 & 22.5 & 23.6 & 25.1 & 2.30 & 4.3 & 5.8 & 10.71 & 13.0 & 13.7 \\
\hline 60 & 26.4 & 27.3 & 29.8 & 4.23 & 5.0 & 6.7 & 13.00 & 15.3 & 15.9 \\
\hline
\end{tabular}

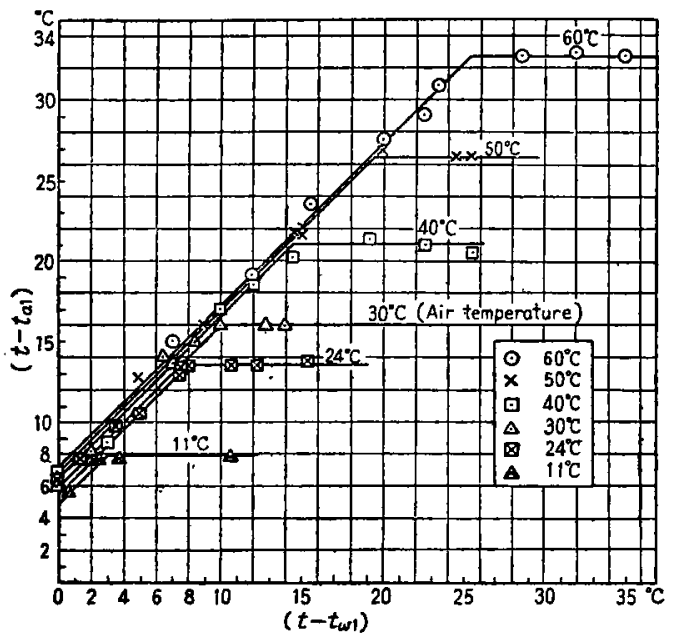

Fig. 5 (A) Wet-bulb depression of toluene

むって液表面温度として Table 1 に示した。この表に 見られるように溶剤の湿球温度より少し低い值となって いる。これらの湿球温度は, われらの前の研究 ${ }^{10)}$ にょ て得られた Fig. 5 (A), (B), (C) によったるのである。 なお液表面温度が湿球温度より少し低いのは前者が（5） 式より計算されたので，輻射などの影留が全く入ってい ないためと思われる。

(5) 式からの $t_{a 1}^{\prime}$ あるいは (8) 式からの $t_{a 1}$ は輻射な どの影警を受けていない值であるから，以後の熱伝達の 計算にはこれらの值を用いて行うことにする。

さて蒸発量を $W$, 蒸発面積を $A$ とすれば，単位面積, 単位時間当りの蒸発熱量は $r_{a} W / A$ となりこれは実湘 值であるからこれから輻射熱による影部を差引くと

$$
r_{a} W / A-Q_{R} / A=h_{b}\left(t-t_{a 1}{ }^{\prime}\right)
$$

なる平衡式が成立する。（6）式より $h_{0}$ を算出するにあ

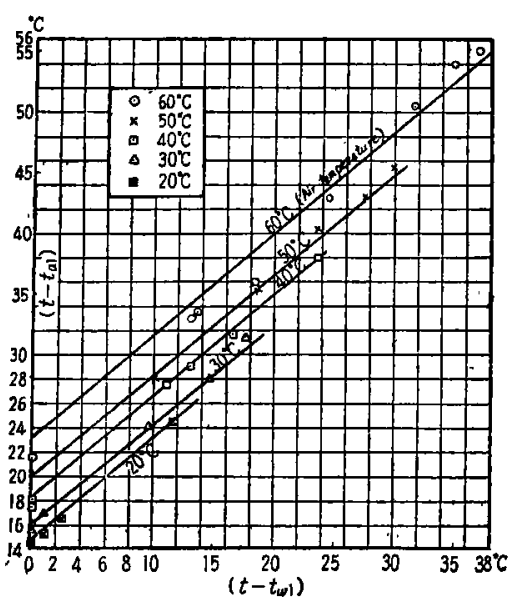

Fig. 5 (B)

Wet-bulb depression of methyl alcohol

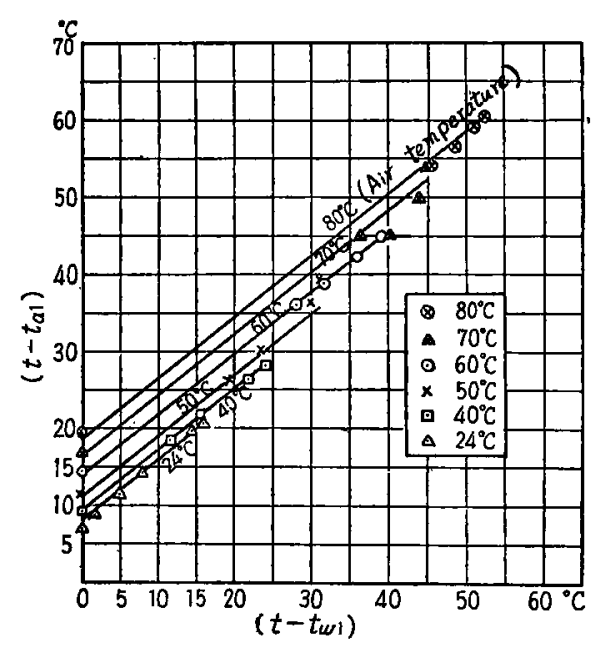

Fig. 5 (C)

Wet-bulb đepression of ethyl alcohol
たって $t_{a 1}{ }^{\prime}$ には, 上述のことく(5) 式より計算した值 (Table 1) を使い. $Q_{R} / A$ には国井 9 の輻射伝熱の理論 によって計算した 値を用いた。しか し $Q_{R} / A$ は輻射の 影響の最も激しい 場合で $r_{a} W / A$ の 約 1 割程度であ る゙このよ5にし $\tau$,（6）式上り求 めた $h$ 。 をFig. 6 に示す。の図に

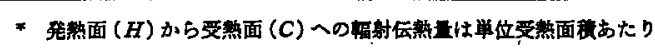
$\frac{Q_{R}}{A}=\frac{Q_{B C}}{A C}=\frac{A R}{A C} \phi B C(4.96)\left\{\left(\frac{273+t}{100}\right)^{4}-\left(\frac{273+t_{a 1} 1^{4}}{100}\right)^{4}\right\}$

[kcal $/ \mathrm{m}^{2} \mathbf{h r}$ ]

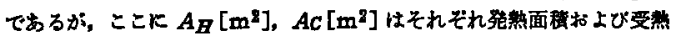

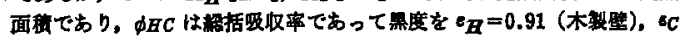

$=0.65$ (液体として本を取った) とすれば，本研究での荥発室の $\phi E C は$

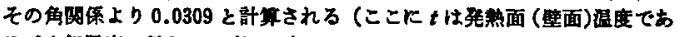
るが空空温度に等しいと考えた)。

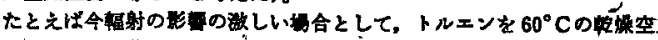

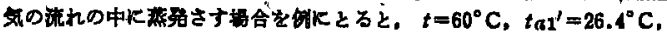

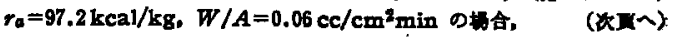


見ることく、いずれの溶剤についてもこの程度の温度筑

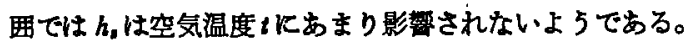

(ii) 湿潤空気の堨合

空気中梑水蒸気がふくまれると，水は自分と非親和性 の溶绪，例えばトルェンのこときすのには凝縮によっ て，親和性のフルコールのこときるのには吸収によって 液体の形で溶剤に入り込む。*゙このために凝縮熱などの

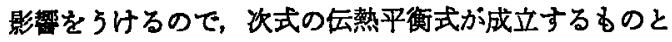
考爷られる。すなわち

$$
r_{a} W / A-Q_{R} / A=h_{a}\left(t-t_{a 1}\right)+q_{\infty}
$$

ここに $q_{w}=r_{w} k^{\prime}\left(H_{w}-H_{w a 1}\right)$ である。ただしここには 吸収熱を疑縮熱と比較して無視してある。また（7）式の

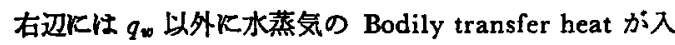
ろが，その熱量は $q_{w}$ に比でて僅少であるので無視した。

(7) 式において $q_{w}$ 中の $k^{\prime} に(4)$ 式を入れると，

$$
\begin{gathered}
r_{a} W / A-Q_{R} / A=h_{s}\left(t-t_{a 1}\right)+r_{w} h_{w}\left(H_{w}-H_{w a 1}\right) \\
/\left\{(S c / P r)_{w}^{1 / 2} \cdot c\right\}
\end{gathered}
$$

(8) 式において実湘值 $W$ の中には，輻射および空気中 の水分の影響を含んでいるのでこれらを差引いてある。 そうすると純空気と液面との熱交換のみの熱量となるの で $h_{b}$ Kは (6) 式で求めたそれそれの $t$ K対する $h_{8}$ を入 れた。な特 $h_{w}$ Kは溶㓣の蒸発の場合と同じ装置で同じ 方法で水を蒸発さして得だ゙ータを基にして（6）式を 使って計算したそれぞれの $t$ に対する $h_{\text {w }}$ の值 (Table 2)を入れた。また（8）式中の $H_{\text {wa1 }}$ は $t_{a 1}$ に和ける湿 り空気の絶対湿度であるが，これは $H_{\text {wa1 }}=0.622 P_{\text {wal }} /$

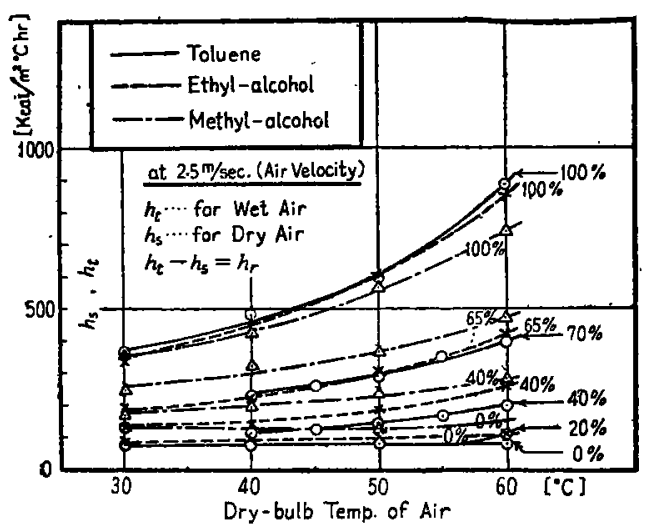

Fig. 6

Heat transfer coefficient vs. air temperature ( $\%=$ Humidity percentage of water in air)

（前具上り） $\mathrm{raW} / A=3010 \mathrm{kcal} / \mathrm{m}^{2} \mathrm{hr}$ となり, これK対して $Q_{R} / A$ $=Q_{H C} / A C=57.6 \times 0.0309 \times 4.96 \times 43.3=382.5 \mathrm{kcal} / \mathrm{m}^{2} \mathrm{hr}$ となる。 この上ろに㳊しいと考えられる状筧でる，QR/A は raW/AK比べて为

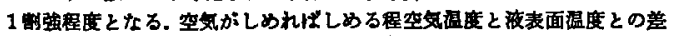
が小となるから QR/A はな枋さら小となる。

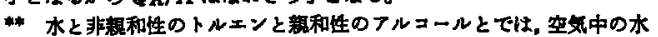

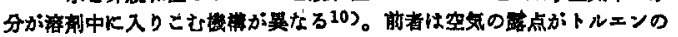

$\left\{760-\left(\left(p_{w a 1}+p_{a 1}\right)\right\}\right.$ 上り計算した。この式中 $p_{w a 1}, p_{a 1}$

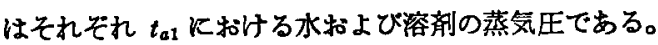
（8）式にこれらの值を入れて $t_{a 1}$ を計算したのであるが， この結果が Table 3にあらわされている。これらは Fig. 5 (A)，(B)，(C) 上り求めた溶剤の湿球温度に近い值で ある(大部分の $t_{a 1}$ は湿球温度より低い。このようにし て福が求められると,

$$
\left(h_{\mathrm{o}}+h_{\mathrm{r}}\right)\left(t-t_{a 1}\right)=\frac{r_{a} W}{A}-\frac{Q_{R}}{A}
$$

なる层熱平衡式より

$$
h_{\mathrm{r}}=\frac{\left(r_{a} W-Q_{R}\right)}{A\left(t-t_{a 1}\right)}-h_{a}
$$

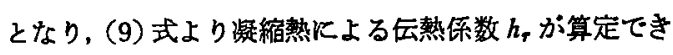
る。Fig. 6 Кは

$$
h_{t}=h_{\mathrm{a}}+h_{r}
$$

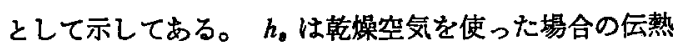
係数であるから，四より $h_{\mathrm{r}}$ 忙 $h_{\mathrm{r}}=h_{\mathrm{t}}-h_{\mathrm{a}}$ Kよって求め

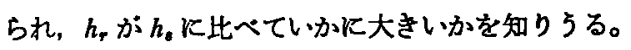

\section{III·2 空気の流速による影㻗}

Fig. $7 \mathrm{~K}$, 蒸発室での平均空気温度 $t=30^{\circ} \mathrm{C}$ の場 合に抽る空気流速および湿度の熱云達係数に及にす影 暗がしめされている。この図に扰いて湿度が高い場合の 万が流速の $h_{t}$ に対する影響が大きいことを知る。

さて乾燥空気の場合化は（4）式のフナロジー式が成立 するか，水蒸気炕よる湿閏空気の場合には，われわれが さきに発表した論文10》にるついて。

$$
\begin{aligned}
& h_{t} / k^{\prime}=\left(S_{c} / P r\right)^{1 / 2} \cdot c \cdot e^{n} \\
& \text { ただし } e=\frac{H_{a 1}-H_{a}}{H_{a 1}^{\prime}-H_{a}} \frac{t-t_{a 1}^{\prime}}{t-t_{a 1}}
\end{aligned}
$$

なる式を提唱し，この関係拉よび（4）式を使って， 乾燥空気に対して

$$
J=\frac{h_{s}}{c G}\left(P_{r}\right)^{1 / 2}=\frac{k^{\prime}}{G}\left(S_{c}\right)^{1 / 2}
$$

Table 2

Coefficient of Heat Transfer of Water $\left(h_{w}\right)$ at Air Velocity $2.5 \mathrm{~m} / \mathrm{sec}$

\begin{tabular}{cc} 
Air Temp. $t^{\circ} \mathrm{C}$ & $h_{w o} \mathrm{kcal} / \mathrm{m}^{2} \mathrm{hr}^{\circ} \mathrm{C}$ \\
\hline 30 & 74.0 \\
40 & 70.8 \\
50 & 70.2 \\
60 & 80.0
\end{tabular}

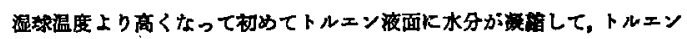

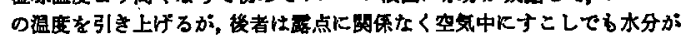

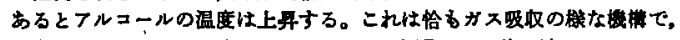

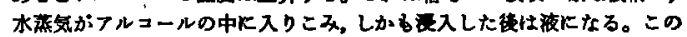

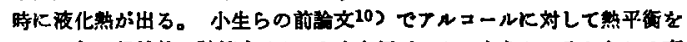

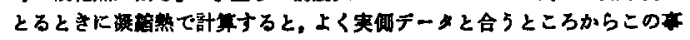
が云えると思5。 
Table 3 Surface Temperature $\left(t_{a 1}\right)$, Wet-bulb Temperature, and Liquid Temperature of Solvents in Vaporization Pan, When Water-wet Air Is Used

\begin{tabular}{|c|c|c|c|c|c|c|c|c|c|c|}
\hline \multirow{3}{*}{ 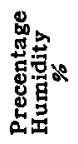 } & \multirow{3}{*}{ 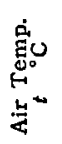 } & \multicolumn{3}{|c|}{ Toluene } & \multicolumn{3}{|c|}{ Methyl-alcohol } & \multicolumn{3}{|c|}{ Ethyl-alcohol } \\
\hline & & \multicolumn{2}{|c|}{$t_{a 1}^{\circ} \mathrm{C}$} & \multirow{2}{*}{$\begin{array}{l}\text { Liquid Temp. } \\
\text { in Vaporiza. } \\
\text { tion Pan } \\
\left({ }^{\circ} \mathrm{C}\right)\end{array}$} & \multicolumn{2}{|c|}{$t_{a 1}^{\circ} \mathrm{C}$} & \multirow{2}{*}{$\begin{array}{l}\text { Liquid Temp. } \\
\text { in Vaporiza- } \\
\text { tion Pan } \\
\left({ }^{\circ} \mathrm{C}\right)\end{array}$} & \multicolumn{2}{|c|}{$\operatorname{ta1}{ }^{\circ} \mathrm{C}$} & \multirow{2}{*}{$\begin{array}{c}\text { Liquid Temp. } \\
\text { in Vaporiza- } \\
\text { tion Pan } \\
\left({ }^{\circ} \mathrm{C}\right)\end{array}$} \\
\hline & & $\begin{array}{l}\text { Value from } \\
\text { Eq. (8) }\end{array}$ & $\begin{array}{l}\text { Wet-bulb } \\
\text { Temp, }\end{array}$ & & $\begin{array}{l}\text { Value from } \\
\text { Eq. (8) }\end{array}$ & $\begin{array}{l}\text { Wet-bulb } \\
\text { Temp. }\end{array}$ & & $\begin{array}{l}\text { Value from } \\
\text { Eq. ( } 8 \text { ) }\end{array}$ & $\begin{array}{l}\text { Wet-bulb } \\
\text { Temp. }\end{array}$ & \\
\hline 20 & $\begin{array}{l}30 \\
40 \\
50 \\
60\end{array}$ & $\left.\begin{array}{l}13.0 \\
18.0 \\
22.5\end{array}\right\}=t a^{\prime} 1$ & $\begin{array}{l}14.0 \\
19.0 \\
23.6 \\
29.9\end{array}$ & $\begin{array}{l}15.0 \\
21.5 \\
25.1 \\
31.8\end{array}$ & & & & & & \\
\hline \multirow{3}{*}{40} & $\begin{array}{l}30 \\
40 \\
45\end{array}$ & $\begin{array}{l}20.4 \\
24.2\end{array}$ & $\begin{array}{l}21.6 \\
25.8\end{array}$ & $\begin{array}{l}23.0 \\
26.3\end{array}$ & $\begin{array}{r}4.0 \\
10.8\end{array}$ & $\begin{array}{r}5.6 \\
11.8\end{array}$ & $\begin{array}{r}7.1 \\
13.3\end{array}$ & $\begin{array}{l}10.4 \\
17.1\end{array}$ & $\begin{array}{l}13.0 \\
18.6\end{array}$ & $\begin{array}{l}14.1 \\
19.8\end{array}$ \\
\hline & \multirow{2}{*}{$\begin{array}{l}50 \\
55 \\
60\end{array}$} & \multirow{2}{*}{$\begin{array}{l}29.1 \\
34.0 \\
39.2\end{array}$} & \multirow{2}{*}{$\begin{array}{l}30.5 \\
34.2 \\
39.0\end{array}$} & \multirow{2}{*}{$\begin{array}{l}32.2 \\
35.8 \\
42.1\end{array}$} & 20.1 & 19.2 & 22.0 & 26.2 & 28.0 & 31.8 \\
\hline & & & & & 28.4 & 26.0 & 28.8 & 35.2 & 34.8 & 37.5 \\
\hline \multirow{3}{*}{ 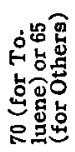 } & \multirow{3}{*}{$\begin{array}{l}30 \\
40 \\
45 \\
50 \\
55 \\
60\end{array}$} & $\begin{array}{l}27.15 \\
31.60\end{array}$ & $\begin{array}{l}27.80 \\
34.00\end{array}$ & $\begin{array}{l}28.3 \\
32.5\end{array}$ & $\begin{array}{r}7.75 \\
19.75\end{array}$ & $\begin{array}{r}9.4 \\
17.2\end{array}$ & $\begin{array}{l}10.7 \\
19.5\end{array}$ & $\begin{array}{l}14.85 \\
23.50\end{array}$ & $\begin{array}{l}16.0 \\
25.4\end{array}$ & $\begin{array}{l}18.3 \\
27.7\end{array}$ \\
\hline & & \multirow{2}{*}{$\begin{array}{l}36.50 \\
42.45 \\
47.60\end{array}$} & \multirow{2}{*}{$\begin{array}{l}37.40 \\
42.20 \\
47.00\end{array}$} & \multirow{2}{*}{$\begin{array}{l}38.4 \\
44.6 \\
48.5\end{array}$} & 26.25 & 24.7 & 27.2 & 33.00 & 33.3 & 35.4 \\
\hline & & & & & 33.75 & 32.0 & 34.9 & 42.35 & 40.8 & 44.0 \\
\hline 100 & $\begin{array}{l}30 \\
40 \\
50 \\
60\end{array}$ & $\begin{array}{l}23.0 \\
32.5 \\
42.3 \\
53.6\end{array}$ & $\begin{array}{l}24.0 \\
33.4 \\
43.1 \\
52.8\end{array}$ & $\begin{array}{l}24.5 \\
33.6 \\
44.0 \\
53.5\end{array}$ & $\begin{array}{l}12.1 \\
20.6 \\
31.1 \\
39.8\end{array}$ & $\begin{array}{l}13.8 \\
21.8 \\
30.0 \\
37.5\end{array}$ & $\begin{array}{l}14.8 \\
22.6 \\
32.0 \\
40.4\end{array}$ & $\begin{array}{l}19.2 \\
30.0 \\
39.0 \\
48.0\end{array}$ & $\begin{array}{l}20.8 \\
30.2 \\
39.0 \\
46.0\end{array}$ & $\begin{array}{l}21.2 \\
31.2 \\
41.5 \\
49.8\end{array}$ \\
\hline
\end{tabular}

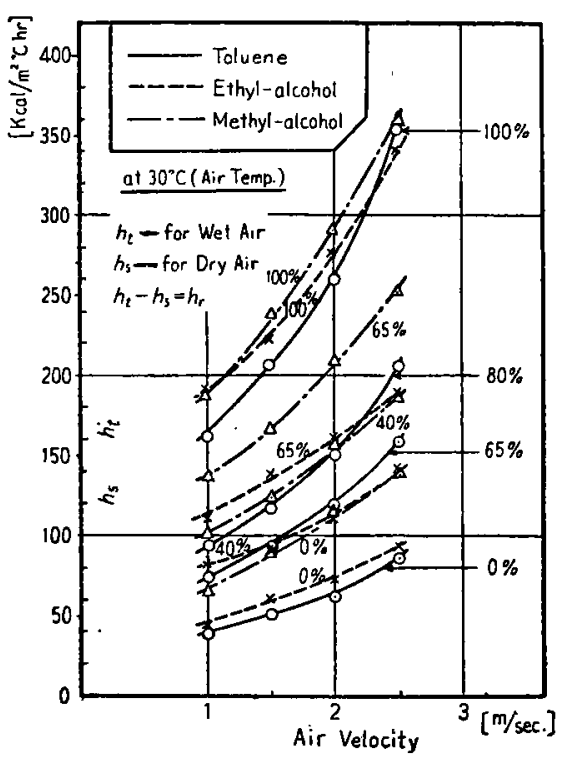

Fig. 7

Heat transfer coefficient vs air velocity

( $\%=$ Humidity percentage of water vapor in air)

湿潤空気に対して

$$
J=\frac{h_{t}}{c G}(P r)^{1 / 2}=\frac{k^{\prime}}{G}(S c)^{1 / 2} \varepsilon^{\mathrm{n}}
$$

とかくと，これら両式はJ因子の関係をあらわすことに なる。今 $h /(c G)=S t$ (Stanton 数) である故両式の左 边を

$$
S_{t}\left(P_{r}\right)^{1 / 2}=b_{1}\left(R_{e}\right)=
$$

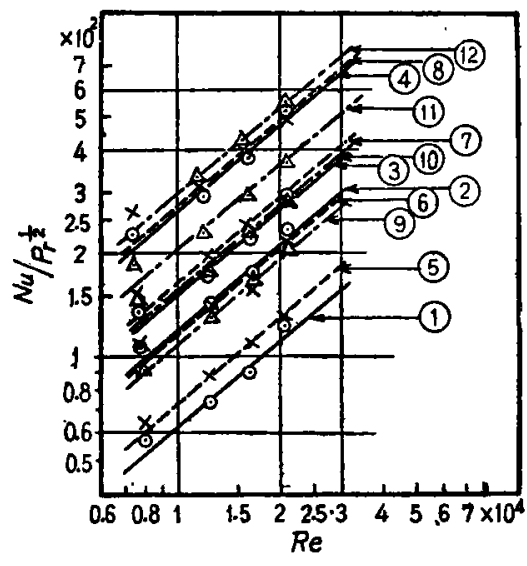

Fig. 8 Relation between $N u / P r^{1 / 2}$ and $R e$ in Eq. (14)

Slope of each linear line is represented by $(m+1)$ which is equal to 0.8

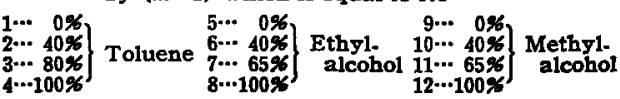

( $\%$ =Percentage humidity of water vapor in air)

と就き， $S t=N u /(\operatorname{Re} \cdot \operatorname{Pr})$ の関保を入れると，

$$
N u=b_{1}(R e)^{m+1}(P r)^{1 / 2}
$$

(14）式に実験值を入れてこの式の関係を画くと Fig. 8 のことくなり $m+1 \div 0.8$ となり,この值は Colburn ${ }^{2)}$, Brown ${ }^{13}$, Shepherd ${ }^{8)}$, 水科等() のしめした值と同一て ある。この場合には (13) 式の $m$ は -0.2 となり，Jurges, Elias, Fage and Falkner の平板上の伀熱実験值を るとにして作った Hopf ${ }^{32}$ の式にる一致している。 
また（12）式において $e^{\Delta}$ を左辺に移し，J=h/(cG). $P^{1 / 2 \cdot 1 / s^{n}}$ として

$$
\text { “ } \quad S t(P r)^{1 / 2}=b_{2}(R e)^{m} \varepsilon^{n}
$$

と蛙くことができる。よって (14) 式と同様に

$$
\mathrm{Nu}=b_{2}(R e)^{m+1}(P r)^{1 / 2} \varepsilon^{n}
$$

\section{となしうる。}

今 $m+1=0.8$ として各項に実駼値を入れて図を画く と Fig.9 のことくなり，ものべき数 $n$ は水に非親和性 のトルエンの場合には1 となり, 水に親和性のエチルフ ルコールおよびメチルフルコールの場合には，それぞ れはぽ0.8，0.84 となる。このnの値はわれわれがさき $飞^{103}$ 湿球を使って求めたそれそれれの $\left(t-t_{w 1}\right)$ 対 $\left(t-t_{a 1}\right)$ 線図 (Fig. 5 (A)，(B)，(C)）の直線の傾斜をしめす値飞 等しくなるよ5である。(16) 式は

$$
\mathrm{Nu}=b_{2}(R e)^{0.8}\left(P_{r}\right)^{0.5 \varepsilon^{n}}
$$

そなり，また（15）式は（18）式となる。すなわち

$$
J=S t(P r)^{0.5}=b_{2}(R e)^{-0.2} \varepsilon^{*}
$$

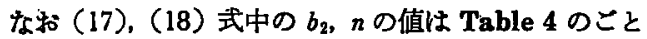
〈なる。

$n$ の値についての比較は上に述べたのであるが， $b_{2}$ の

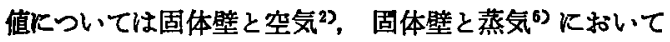
それぞれ 0.036，0.0235 の值が得られているが，われわ れの值 (Table 4) 沬これより大となっている。これは 蒸発皿の緑や液面のみだれの影留のためと考兄られる。 ちなみに Millarうによって, 風洞中の蒸発器について求 められた值は 0.051 である。また $\mathrm{e}$ は空気中の水蒸気の 有機溶剤炕対する影響をしめするので (17) 式において この項とRe の項の相乗積が大きくNu影響すること を知る。Fig. 7 るよくそれを物語っている。

計算にあたって Sc中Pr中含をれる それそれの温度におけるるのをとりＤは特のおのの溶 用の蒸気について物性定数推算法》によって計算したる のである。

\section{§ IV. 藉 論}

(1) トルエン, エチルフルコール, メチルフルコール の蒸発率江乾燥空気によるよりる，办蒸気を含んた空気 飞よる方が大である（Fig. 3，4)。この主因は水蒸気の 凝鏥熱に上るるのである。

(2) 空気に上る液の蒸発《忙 $S_{c}, \operatorname{Pr}=0.5 \sim 2.5$ の範 团飞就いて（10）式が適用される。ただし乾燥空気の場

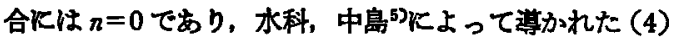
式になる。水蒸気を含んだ空気の場合には蒸発さすへき 液の種類によってnが異なる。

(3) 水蒸気の凝維熱の $h_{\mathrm{l}}$ 亿対する影锌は非常に大き い。とくに飽和空気の場合には $h_{r} \gg h$ ，(Fig. 6, 7)。

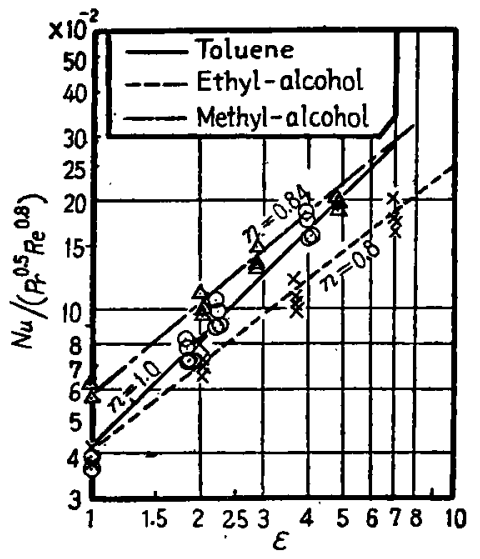

Fig. 9 Relation between $N u /\left(P r^{0.5} R^{0.8}\right)$

\begin{tabular}{|c|c|c|c|}
\hline $\begin{array}{l}\text { Air } \\
\text { Condition }\end{array}$ & $\begin{array}{l}\text { Liquid in } \\
\text { Vaporization Pan }\end{array}$ & $b_{2}$ & $n$ \\
\hline Water-wet Air & $\begin{array}{l}\text { Toluene } \\
\text { Ethyl-alcohol } \\
\text { Methyl-alcohol }\end{array}$ & $\begin{array}{l}0.0367 \\
0.0401 \\
0.0629\end{array}$ & $\begin{array}{l}1.00 \\
0.80 \\
0.84\end{array}$ \\
\hline Dry Air & $\begin{array}{l}\text { Toluene } \\
\text { Ethyl-alcohol } \\
\text { Methyl-alcohol }\end{array}$ & $\begin{array}{l}0.0367 \\
0.0401 \\
0.0629\end{array}$ & $\begin{array}{l}0 \\
0 \\
0\end{array}$ \\
\hline
\end{tabular}
and $\varepsilon$ in Eq. (17)

\section{Table 4}

Values of $b_{2}$ and $n$ in Eq. (17), (18)

(4) 実験結果ははぼ (17)，(18) 式によってあらわさ れる (Fig. 9 参照)。

\section{Nomenclature}

$A$ : Area of vaporization surface $\left[\mathrm{m}^{2}\right]$

$a$ : Thermometric conductivity of air $\left[\mathrm{m}^{2} / \mathrm{hr}\right]$ $b_{1}, b_{2}$ : Constant

$c:$ Specific beat of air [kcal $\left./ \mathrm{kg}^{\circ} \mathrm{C}\right]$

$D$ : Diffusivity of air $\left[\mathrm{m}^{2} / \mathrm{hr}\right]$

$G:$ Mass velocity $\left[\mathrm{kg} / \mathrm{m}^{2} \mathrm{hr}\right]$

$H_{a}$ : Absolute humidity of solvent

[kg solvent/kg dry air]

$H_{a 1}, H_{a 1}^{\prime}$ : Absolute humidity of solvent at $t_{a 1}$,

$t_{a 1}{ }^{\prime}$, respectively [ $\mathrm{kg}$ solvent/kg dry air]

$H_{\infty}$ : Absolute humidity of water

[kg water $/ \mathrm{kg}$ dry air]

$H_{w a 1}$ : Absolute humidity of water

at $t_{a 1}$

[kg water/kg dry air]

$h$ : Coefficient of heat transfer [kcal $\left./ \mathrm{m}^{2} \mathrm{hr}{ }^{\circ} \mathrm{C}\right]$

$h r:$ Coefficient of heat transfer of solvent when affected by latent heat of water vapor, as shown by Eq. (9)

$\left[\mathrm{kcal} / \mathrm{m}^{2} \mathrm{hr}{ }^{\circ} \mathrm{C}\right]$ 
$h_{t}=h_{\mathbf{a}}+h_{\text {r }}$

[kcal $\left./ \mathrm{m}^{2} \mathrm{hr}{ }^{\circ} \mathrm{C}\right]$

$h_{\varepsilon}$ : Coefficient of heat transfer of solvent when not affected by water vapor in air

[kcal $/ \mathrm{m}^{2} \mathrm{hr}{ }^{\circ} \mathrm{C}$ ]

$h_{w}$ : Coefficient of heat transfer of water

$\left[\mathrm{kcal} / \mathrm{m}^{2} \mathrm{hr}{ }^{\circ} \mathrm{C}\right]$

$h / k^{\prime}$ : Psychromatic ratio

$k^{\prime}$ : Coefficient of mass transfer $\left[\mathrm{kg} / \mathrm{m}^{2} \mathrm{hr} \Delta H\right]$

$L$ : Length of vaporization surface parallel to the direction of flow

$N u=h L / \lambda:$ Nusselt number

$P_{r}=y / a:$ Prandtl number

$Q_{R}:$ Heat transferred by radiation [kcal/hr]

$q_{w}$ : Heat transferred mostly by condensation of water vapor

[kcal $\left./ \mathrm{m}^{2} \mathrm{hr}\right]$

$R_{\ell}=G L / \mu:$ Reynolds number

$r_{a,} r_{w}$ : Latent heat of solvent and that

of water respectively

[kcal/kg]

$S c=\nu / D:$ Schmidt number

$S_{t}=h /(c . G):$. Stanton number

$t$ : Temperature of air

$t_{a 1}$ : Wet-bulb temperature of air, containing water vapor as measured with wet-bulb of solvent, and surface temperature of evaporation pan

$t_{a 2}{ }^{\prime}$ : Wet-bulb temperature of air, containing no water vapor as measured with wet bulb of solvent, or Wet-bulb temperature of air not affected by water vapor in air $\left[{ }^{\circ} \mathrm{C}\right]$, and surface temperature of evaporation pan

$t_{w 1}$ : Temperature of water-wet air as measured with wet-bulb of water

$W:$ Vaporization rate $[\mathrm{kg} / \mathrm{hr}]$ $\varepsilon=\left\{\left(H_{a 1}-H_{a}\right) /\left(H_{a 1}{ }^{\prime}-H_{a}\right)\right\} \cdot\left\{\left(t-t_{a 1}{ }^{\prime}\right) /\left(t-t_{a 1}\right)\right\}$

$\lambda$ : Thermal conductivity of air [kcal/mhr ${ }^{\circ} \mathrm{C}$ ]

$\mu$ : Viscosity of air

[kg/mbr]

$\nu$ : Kinematic viscosity of air

$\left[\mathrm{m}^{2} / \mathrm{hr}\right]$

\section{Literature cited}

1) Brown, G. G.: "Unit Operation," p. 569 (1951)

2) Colburn, A. P. Trans. Am. Inst. Chem. Eng., 29, 174 (1933)

3) Hopf, L., in Geiger, H. and Scheel, K. : "Handbuch der Physik," 7, 158 (Springer, 1927)

4) Millar, I. G. . Canadian Meteorological Memoris, 1, 43 (1937)

5) Mizushina, T. \& Nakajima, M.: Chem. Eng.(Japan), 15, 30 (1951)

6) Mizushina, T. et al: Chem. Eng. (Japan), 17, 152 (1953)

7) Satō, K. : “'Bussei-Teisu-Suisanho," (Estimation Method of physical Properties), p. 129 (Maruzen Co, Japan, 1954)

8) Shepherd, et al : Ind. Eng. Chem., 30, 388 (1938)

9) Yagi, S. \& Kunii, D. - " Kagaku-Kōgaku-To-Kagaku. Kikai," (Chemical Engineering and Chemical Appa. ratus), 8, 11 (Soc. of Chem. Eng.; Japan)

10) Yoshida. T. \& Hyōdō, T.: Chem. Eng. (Japan), 2n, 536 (1956)

\section{Vaporization, in Water-Wet Air, of Organic Solvents}

\section{Tetsuo Yoshida* and Tsutomu Hyōdō*}

In our previous report ${ }^{10)}$ we made it clear that water vapor contained in air greatly influenced the wet-bulb temperatures of organic solvents. Based on the idea that one might obtain higher rate of vaporization by using water-wet air rather than dry air, our studies were continued with a view to throwing light on how the vaporization of organic solvents into water-wet air would be affected by water-vapor content thereof.

The present results obtained with toluene, ethyl-alcohol and methyl-alcohol clearly, proved that we were right in supposing that water-wet air would bring about higher rate of vaporization than dry air, as shown in Figs. $3 \& 4$. Here the curves for methyl-alcohol are omitted in order to avoid complication.

I. Effects of Temperature of Air and Its Water-vapor Content upon $h t$ :

(i) In Dry Air:

The surface temperatures of liquids in the vaporization pan were calculated by means of Eq. (5), derived from Eq. (1) and Mizushina \& Nakajima's Eq. (4) ${ }^{5)}$, which is said to be applicable over the region where $S c, P r=0.5 \sim 2.5$. The results tabulated in Table 1 show that these surface tem- 
peratures are $1 \sim 2^{\circ} \mathrm{C}$ lower than the wet bulb temperatures of the same organic solvents, which we measured in our previous experiments ${ }^{102}$-Cf. Fig. 5-(A), (B) \& (C). Of these two kinds, the lower temperatures seem to be the real surface temperatures, uninfluenced by radiation heat, etc. The values of $h_{a}$, calculated by using Eq. (6), are plotted in Fig. 6 .

(ii) In Water-wet Air :

In Table 3 are shown the surface temperatures $\left(t_{a 1}\right)$ calculated by using Eq. (8), where $h_{8}$ is the value obtained from Eq. (6) and where the absorption heat etc. are ignored because they are negligibly small as compared with condensing heat. Here again the surface temperatures $\left(t_{a 1}\right)$ are almost $1 \sim 3^{\circ} \mathrm{C}$ lower than the wet bulb temperatures. $h r$ can be obtained from Eq. (9). These data are plotted in Fig. 6 as $h_{t}=h_{s}+h_{r}$ vs. dry bulb temperatures of air. The values of $h_{r}$ are known to be considerably larger than those of $h_{\mathrm{s}}$.

II. Effects of Air Velocity upon $h_{t}$ :

The experimental data are plotted in Fig. 7 and correlated as shown in Figs. $8 \& 9$, by means of dimensional group in Eqs. (17) \& (18); $b_{2}$ and $n$ appearing in these are shown in Table 4, too. $\varepsilon$ in the equations is a factor to show the effect of water-vapor content of air upon the vaporization of organic solvents and is equal to 1 when the experiment is conducted in dry air. The powers of Reynolds number in these equations agree with the results obtained by other workers ${ }^{1,2,6,8)}$. The power of Prandtl number is what Mizushina and Nakajima ${ }^{52}$ proposed in their report. The values of $n$. which are the power of $e$, seem to agree with values represented by the slopes of linear lines in the diagrams obtained formerly by us $^{102}$. These lines show the relation between the wet-bulb depression oi organic liquids $\left(t-t_{a 1}\right)$ and the wet-bulb depression of water $\left(t-t_{w 1}\right)-$ Cf. Fig. 5 (A), (B) \& (C).

* Institute of Polytechnics, Osaka City University

\section{R. E. JOHNSTONE \& M. W. Thring :}

\section{Pilot Plants, Models, and Scale-up Methods in Chemical Engineering}

McGraw-Hill Co. INc.

本書は例の McGRAW-HILL 社の Chem. Eng. Seriesの 1 巻として, 1957 年発刊され，307頁よりなって いる

著者が本書において企てたのは，小規模なパイロット ブラントから大規模なプロセスプラントへ開発していく のに役立つ定量的な方法論を組立て，さらにそれを使い 易い形で表示することである。

それには他の工学特に造船, 航空などにおいて碓立さ れている模型理論をケミカルブロセスの分野に新しく学 スして，この企てを成功させた。

すなわち新しいケミカルプロセスをバイロットブラン トから大替模な工羍装置に開発していく分野，ならびに

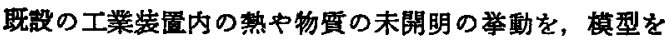
使って研究する分野などに括いて，この模型理論を盖入 した新しい方法を展開して，独創的な成果をあげた。 内容的には，前段の数章で相似性原理，㳄元解析，微 分方程式，支配概念 (Regime Concept)，相似基制々縮 尺方程式 (Scale Equation), 蕒界效果などついて詳
述している。後段を化学工学の各種の単位操作に, 上述 の諸概念を適用した解析的，かつ定量的な取扱いの説明 にあて，著者の新しい企ての成功を実証している。 本書にはかなりの量の数学的取报いが含まれている が，著者もことわっているょ5に，最後の相似模型の章 を除いては大して難しいるのではないようである。

単位操作の各音には適当飞具体的説明事項中数量的取 报いの例題が与えられて，数学的取报いの理解を容易に する配庶がされてはいる。しかしさらに数多くの例题が 盛込まれることにより，著者の新しい企てに対する読者 の安心感を碓かにする必要がありはしなかったかと感ず る。ま化学工学閣係の著書にしては図表に上る説明の 少いのも珍らしい感じがしたし，むっとその点を考虑し

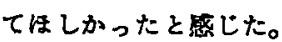

とにかく本荅は化学工学においては最る困奞であるが ゆえに，最る論文，著書などの少い分野の真に得雉い贫 作であると考えるので，同学の方澾の一読を警望する。

(鈴木 明) 